\title{
PANCASILA DAN MULTIKULTURALISME
}

\author{
Risladiba $^{1}$, Suciyadi Ramdhani \\ IAIN Syekh Nurjati Cirebon \\ risladiba24@gmail.com, suciyadiramdhani@gmail.com
}

\begin{abstract}
ABSTRAK
Pancasila merupakan dasar negara yang di dalamnya terkandung nilai-nilai toleransi atau penghargaan terhadap keberagaman yang ada di Indonesia. Pancasila lahir sebagai buah pemikiran yang mendalam dari para pendiri negara, agar Pancasila dapat merangkum berbagai perbedaan untuk kemudian dapat menjaga keutuhan persatuan dan kesatuan bangsa. Multikulturalisme Indonesia menghargai akan adanya kebhinnekaan sebagai implementasi dari nilai Pancasila. Keberagaman yang ada di Indonesia bukanlah hal yang harus diperdebatkan atau menimbulkan perpecahan tetapi bagian dari unsur-unsur yang membentuk kesatuan. Metode yang digunakan dalam penulisan artikel ini adalah studi literatur, yakni dengan mengumpulkan data yangrelevanyang terkaitdengankajian pembahasan dalam penulisan artikel ini untuk kemudian dilakukan analisis sehingga menghasilkan ide atau gagasan.Hasil penelitian ini antara lain adalahbahwa Pancasila dirancang agar dapat mewadahi keragaman yang ada. Pancasila sebagai ideologi negara juga pedoman dalam berkehidupan bermasyarakat, berbangsa dan bernegaramewadahi keberagaman, baik budaya, etnis, ras agama sehingga terbentuklah negara kesatuan Indonesia.
\end{abstract}

\section{Kata Kunci: Pancasila; Multikulturalisme}

\begin{abstract}
Pancasila as the basis of the state contains values of tolerance or respect for diversity in Indonesia. Pancasila was born as the fruit of deep thought from the founders of the state, so that Pancasila can encapsulate various differences in order to then be able to maintain the integrity of the nation's unity and integrity. Indonesian multiculturalism recognizes the cultural diversity of the ethnic groups in Indonesia as an implementation of the values of Pancasila. The diversity of the cultures of the Indonesian ethnic groups is not a separator but is an element of unity. The method in this writing uses literature studies, namely by collecting relevant data related to the discussion study in writing this article for later analysis to produce ideas or ideas. The results of this study include that Pancasila is designed to accommodate the existing diversity. Pancasila as the state ideology is also a guideline in living in a community, nation and state where the diversity of cultures, religions, ethnicities and races meet and there is a nation state formed.
\end{abstract}

Keywords: Pancasila; Multiculturalism

Jurnal Edueksos Vol. X, No. 1, Juni 2021

The journal of social and economic education 


\section{A. PENDAHULUAN}

Indonesia merupakan negara dengan berbagai macam suku, budaya, adat istiadat, agama, bahasa dan masih banyak keberagaman lainnya. Keberagaman tersebut merupakan pemberian Tuhan yang harus dinikmati, dimanfaatkan dan dilestarikan. Dengan keberagaman tersebut, bangsa Indonesia memiliki sifat pluralistik. Indonesia sebagai bangsa yang plural memiliki ratusan budaya, agama, etnis dan adat istiadat yang tersebar di berbagai pulau.

Kymlicka (2004:263) menyebutkan bahwa hak-hak yang membedakan kelompok akan mengurangi rasa jati diri warga negara yang sarna yang mengikat masyarakat, hak-hak itu akan menjadi sumber perpecahan yang dapat mengarah pada bubarnya negara atau pada berkurangnya keinginan untuk saling berkorban dan menyesuaikan diri yang diperlukan untuk berjalannya demokrasi. Pernyataan tersebut sangat relevan dengan kondisi bangsa Indonesia yang majemuk yang disatu sisi dapat memperkaya khasanah budaya bangsa tetapi disisi lain rawan terhadap konflik horizontal yang mengancam disintegrasi bangsa. Perbedaan itu seharusnya diakui sebagai suatu kekayaan yang menjadi potensi bagi berkembangnya pola kehidupan yang adil dan beradab, bukan untuk menimbulkan sikap diskriminatif. Sehingga hal yang penting dalam multikulturalisme yakni perbedaan dan penghargaan.

Masyarakat Indonesia dengan pluralitas dan heterogenitasnya tersebut disatukan dalam semboyan "Bhinneka Tunggal Ika", yang bermakna walaupun Indonesia memiliki banyak keragaman, tapi terintegrasi dalam kesatuan. Semboyan tersebut sebagai falsafah kehidupan berbangsa dan bernegara, dapat dikategorikan pada negara yang realitas etnis dan budayanya heterogen (Budimansyah, 2016: 157). Bangsa Indonesia adalah bangsa yang multikultural. Untuk mewadahi hal tersebut dibutuhkan pedoman yang dijadikanacuan atau prinsip yang digunakan dalamkehidupan sehari-hari. Adanya pedoman tersebut diharapkan mampu mengakomodir berbagai komponen bangsa agar tidak menimbulkan suatu perpecahan atau konflik.

Pancasila di dalamnya terkandung nilai-nilai yang digali dari kehidupan masyarakat Indonesia sejak zaman dahulu, nilai-nilai tersebut merupakan 
kepribadian bangsa Indonesia. Adanya implementasi nilai-nilai Pancasila di dalam kehidupan bermasyarakat, berbangsa dan bernegara harus timbul dari masyarakat Indonesia sendiri yang berarti bahwa Pancasila memang dibutuhkan sebagai pegangan dan pedoman dalam kehidupan bermasyarakat, berbangsa, dan bernegara. Sebagaimana diungkapkan oleh Widjaja (2000: 2), bahwa:

Pancasila membangkitkan kesadaran akan dirinya atas pengembangan tanggung jawab pribadi terhadap kehidupan masyarakat dan sebaliknya, serta menimbulkan kesadaran dan kemauan untuk senantiasa dapat mengendalikan diri dan kepentingan, agar tercipta keseimbangan, keselarasan dan keserasian kehidupan masyarakat atas dasar kesadaran hukum yang berlaku. Hukum, perilaku manusia, dan masyarakat haruslah ditujukan atau terpusat pada perwujudan nilai-nilai luhur Pancasila, sehingga baik manusia maupun masyarakat sikap dan perilaku timbul atas dorongan sebagai kesadaran hukum untuk mewujudkan kehidupan sejahtera dan bahagia dengan dilandasi oleh nilai-nilai luhur Pancasila dari segala implikasinya.

Berdasarkan penjelasan Widjaya tentang Pancasila tersebut, dapat disimpulkan bahwa setiap masyarakat Indonesia ketika berperilaku dan mengambil sikap hendaknya berpedoman pada nilai-nilai Pancasila. Sehingga, baik dalam kehidupan bermasyarakat, berbangsa dan bernegara terjadi keseimbangan, keselarasan dan keserasian, karena warga negaranya adalah warga negara yang baik dan cerdas yang memiliki kesadaran hukum, bertanggung jawab, memiliki kepedulian dengan lingkungan sekitar dan melaksanakan nilai-nilai Pancasila.

Kelima sila yang terdapat di dalam Pancasila adalah dasar, pedoman, acuan serta landasanyang harus diperhatikan dalam melaksanakan kehidupan bermasyarakat, berbangsa dan bernegara.Dengan demikian, maka konsekuensinya adalah segala perbuatan, tindakan, kebijakan, dan lain sebagainya yang berkaitan dengan negara Indonesia dan unsur-unsur di dalamnya harus berdasar pada nilainilai Pancasila. Pancasila sebagai dasar negara tidak hanya merupakan sekumpulan ajaran moral, tetapi sebuah sistem filsafat. Maknanya bahwa Pancasila adalah suatu rumusan yang ideal dalam membangun Indonesia yang dicita-citakan selama ini (Soedarso, 2006: 48). Pancasila dikenal sebagai system filsafat karena hasil dari pemikiran dan perenungan mendalam dari para pendiri 
negara yang berisikan nilai-nilai yang yang telah melakat pada jati diri bangsa Indonesia sejak dahulu.

Nilai-nilai yang menjadi budaya masyarakat Indonesia pada masa itu oleh para founding fathers disahkan sebagai dasar negara. Para founding fathers menganggap Pancasila merupakan kristalisasi kepribadian bangsa, ajaran yang dinilai paling tepat untuk kondisi bangsa Indonesia yang terdiri dari berbagai suku bangsa dan juga agama. Dengan adanya Pancasila, diharapkan setiap kepentingan dan keinginan dari setiap elemen warga negara Indonesia dapat terakomodasi. Pancasila juga diharapkan dapat menjadi karakter setiap warga negara Indonesia. Nilai-nilai yang terkandung dalam Pancasila mengandung jawaban atas setiap permsalahan yang dihadapi oleh warga negara Indonesia. Selain itu, nilai-nilai yang terkandung dalam Pancasila dapat mengikuti perkembangan zaman.

Latif (2011: 3) memberikan pandangannya tentang Pancasila, yakni Pancasila sebagai warisan dari jenius nusantara yang sesuai dengan karakteristik di dalamnya yang dipenuhi dengan lautan dan pulan-pulau. Dimana berdasarkan sifatnya, bahwa lautan menyerap dan membersihka tanpa mengotori lingkungannya serta mampu menampung segala keragaman yang ada di dalamnya.

Berdasarkan penjelasan tersebut di atas, dapat dimaknai bahwa Pancasila bagi bangsa Indonesia dijadikan sebagai filter atau penyaring dari hal-hal yang tidak sesuai dengan setiap aspek kehidupan masyarakat Indonesia. Pancasila juga dianggap mampu untuk menampung berbagai jenis keberagaman yang ada di Indonesia, baik suku, bangsa, agama, bahasa, dan sebagainya. Karena, hal tersebut merupakan karakteristik bangsa Indonesia sebagai bangsa yang majemuk dengan segala kekhasannya.

\section{B. METODE PENELITIAN}

Metode yang digunakan dalam penulisan artikel ini adalah studi literatur. Studi literature merupakan metode yang digunakan untuk mengumpulkan datadata serta untuk mengungkapkan bahan pembahasan dalam penulisan artikel ini.Studi literatur dilakukan dengan cara membaca serta mempelajari berbagai buku maupun jurnal-jurnal ilmiah yang relevan dan utama yang berkaitan dengan kajian sehingga kemudian dilakukan analisis untuk menghasilkan ide atau 
gagasan penulis.Pembahasan yang ada dalam penulisan artikel ini terkait dengan Pancasila, multikulturalisme, implementasi nilai-nilai Pancasila serta bagaimana penerapan, tantangan dan juga dampaknya dari keberagaman yang ada di Indonesia tersebut. Penggunaan metode studi literatur ini dilakukan untuk memperoleh data teoritis yang dapat mendukung penulisan artikel Faisal (1992:30) menyebutkan bahwa hasil dari studi literature dapat dijadikan sebagai landasan dalam menjelaskan masalah-masalah yang akan diteliti.

\section{HASIL DAN PEMBAHASAN}

Keberagaman di Indonesia merupakan merupakan bagian dari kekayaan yang kita miliki.Adanya semboyan Bhinneka Tunggal Ika menyatukan berbagai macam keberagaman tersebut sebagai kekayaan yang dimiliki bangsa Indonesia. Bila dilihat, di Indonesia terdapat banyak etnis yang dapat hidup berdampingan dengan menjalankan kebudayaan juga tradisinya masing-masing. Hal ini menjadikan Indonesia sebagai salah satu negara multikultural terbesar di dunia (Hanifi, 2016: 83).The only principle that can bind all components of the nation and able to summarize the diversity of the nation's components is Pancasila (Risladiba, 2018).

Indonesia sebagai negara yang majemuk apabila dilihat dari berbagai dimensi yang ada. Dimensi yang paling menonjol diantaranya adalah keragaman etnik atau suku bangsa yang ada. Bahar (1997) menyebutkan bahwa dengan mengacu pada data yang ada di Direktorat Kebudayaan Departemen Pendidikan dan Kebudayaan, di Indonesia terdapat 525 kelompok etnik. Berdasarkan sejarahnya, bisanya kelompok etnik tertentu mendiami sebuah pulau, sehingga keberadaan sebuah pulau di Indonesia sering diidentikan dengan etnik tertentu.

Multikulturalisme yang ada di Indoneisa memiliki kekhasan tersendiri, yakni tumbuh dan berkembang berdasar nasionalisme. Multikulturalisme Indonesia mengakui adanya kebhinnekaan budaya dari berbagai suku bangsa yang ada. Hal tersebut sebagai dasar dari kehidupan Indonesia yang beragam. Keberagaman dari budaya pada suku bangsa tersebut bukanlah dijadikan sebagai hal yang menimbulkan pemisahan tetapi justru sebagai bagian dari unsur kesatuan Indonesia. Maka dari itu, kebudayaan dari suku bangsa tersebut harus dijaga, 
dilestarikan dan dikembangkan dengan prinsip Bhinneka Tunggal Ika. Dari hal tersebut muncul bibit-bibit kebudayaan daerah yang bisa disumbangkan kepada kebudayaan nasional. Adanya proses pengembangan tersebut melalui komunikasi dan dialog yang terwujud melalui bahasa persatuan, yakni bahasa Indonesia.

Magnis Suseno (2005: 216) menyebutkan bahwa bangsa Indonesia sebagai bangsa yang multikultur maka seharusnya dipandang melalui perspektif multikulturalisme, karena negara Indonesia dapat menjadi negara yang utuh dan bersatu apabila keberagaman yang ada dan menjadi kenyataan sosialini dihargai dan dihormati oleh setiap masyarakat. Kekuatan dalam penegakkan persatuan dan kesatuan di negara Indonesia ini bukan bertujuan untuk melenyapkan identitas atau jati diri dari setiap komponen bangsa, akan tetapi bertujuan agar setiap warga negara Indonesia salaing menjunjung tinggi toleransi dengan menghargai satu sama lain tanpa merasa adanya diskriminasi atau merasa diasingkan. Adanya toleransi, saling menghargai dan menghormati serta bersedia untuk tidak memaksakan kehendak sendiri terkait suatu hal kepada yang lain merupakan salah satu cara untuk terwujudnya multikulturalisme Indonesia yang dicita-citakan.

Globalisasi yang terjadi sekarang ini menjadi katalisator terjadinya perubahan sosial karenakemudahan berinteraksi masyarakat di berbagai belahan dunia sehingga salah satunya menyebabkan transkulturasi. Di tengah arus globalisasi tersebut, sebagai bangsa yang besar, Indonesia harus tetap menjaga integitas dan ketahanan nasionalnya, salah satunya melalui kelenturan budaya dan kemampuan untuk tetap beradaptasi dengan budaya luar yang dianggap dapat memberikan dampak positif terhadap budaya lokal. Bangsa Indonesia boleh selalu waspada, dalam artian memfilter berbagai budaya luar yang tidak sesuai dengan nilai-nilai Pancasila, namun tidak berarti bersikap apriori terhadap budaya luar.Semuanya harus dilakukan secara kritis dan bijaksana.

Memasuki era reformasi yang ditandai adanya keterbukaan politik, kebebasan, maka tantangan yang dihadapi bangsa Indonesia pun semakin bertambah. Diantaranya adalah keberadaan masyarakat yg plural dengan etnisitas, ras, agama, gender, dan kebudayaan yang berbeda-beda antara satu dengan lainnya.Tantangan tersbut disa diatasi apabila bangsa Indonesia mengembangkan multikulturalisme berdasarkan nilai-nilai Pancasila. Sebagaimana yang disebutkan 
Kmylicka bahwa, bentuk multikulturalisme harus cair dalam kelompoknya juga adanya kebebasan untuk berafiliasi serta adanya konsepsi identitas kelompok harus non eksklusif (Kymlicka, 2004: 43).

Selain gagasan yang telah disebutkantersebut di atas, maka multikulturalisme di Indonesia harus mengacu kepada nilai-nilai Pancasila. Dengan konsepsi tersebut diharapkan adanya keselarasan dan kesesuaian untuk menjalankan kehidupan berbangsa dan bernegara ini yakni menerima pluralitas dengan berbagai keberagamannya selama hal tersebut tidak bertolak belakang dengan nilai-nilai Pancasila. Indonesia sebagai bangsa yang menjunjung nilainilai Pancasila yang di dalamnya terdapat nilai ketuhanan, kemanusiaan, persatuan, juga keadilan, maka sudah seharusnya dapat menerima pluralitas yang ada sebagai pengamalan dari Pancasila tersebut.

Multikulturalisme ini memiliki dampak positif dan negatif. Salah satu dampak positif yang bisa diambil adalah dapat mengukuhkan persatuan dan kesatuan bangsa. Sedangkan dampak negatif yg harus kita hindari diantaranya adalah menimbulkan perpecahan atau konflik. Kenyataan yg bisa dilihat sekarang ini terkait dengan ancaman multikulturalisme adalah tumbuhnya sifat egosentrisme yang mengatasnamakan agama, suku atau yang lainnya. Apabila sifat tersebut terus terpelihara maka tidak menutup kemungkinan akan memunculkan sikap ekslusivisme yang ditambah dengan masalah ekonomi, sosial, budaya akan memicu timbulnya konflik perselisihan atau bahkan perpecahan. Menjadikan multikulturalisme sebagai kekuatan atas kekayaan Indonesia ini menjadi tantangan bagi kita semua. Dimana apabila tantangan tersebut dapat terjawab dan teratasi maka dapat mewujudkan Indonesia yang berkesatuan dan berpersatuan. Dalam hal ini penting sekali adanya sinergitas antara masyarakat dan pemerintah juga strategi untuk menghindari dampak ngatif tersebut.

Budimansyah (2008) menjelaskan bahwa untuk membentuk masyarakat multikultural Indonesia yang sesuai dengan nilai-nilai Pancasila harus ada upaya yang dilakukan secara sistematis, programatis, integrated dan berkesinambungan. Diantaranya implementasi strategi penting itu melalui pendidikan multikultural yang dapat berlangsung dalam lingkup pendidikan formal atau informal, langsung atau tidak langsung. 
Adanya konflik yang timbul diantara suku bangsa sekarang ini disebabkan karena pemahaman dan penghargaan yang kurang terhadap suku bangsa lain. Maka dari itu, salah satu usaha untuk menyelesaikan permasalahan tersebut dengan melakukan pembinaan atau adanya sosialisasi kepada masyarakat mengenai pentingnya penghargaan antar suku bangsa. Sosialiasasi tersebut dapat dilakukan langsung kepada masyarakat juga melalui lingkup pendidikan di sekolah, khususnya untuk generasi perubahan atau penerus bangsa. Dengan adanya pendidikan kita bisa mengubah mindsetegosentrisme dengan pandangan yang lebih baik untuk menciptakan kondisi yang harmonis, selaras dan seimbang dalam lingkungan multikultural.

Kemungkinan munculnya konflik pada masyarakat multikultur sangat rawan terjadi jika masyarakat multikultur menyikapi perbedaan sebagai suatu pemisah. Masyarakat yang hidup ribuan tahun dalam keadaan yang multikultur tidak berarti telah bebas terhadap kemungkinan-kemungkinan gesekan konflik etnis, budaya, agama, sosial, politik dan ekonomi. Pengalaman lama hidup dalam perbedaan ternyata tidak cukup untuk menanamkan rasa bangga akan perbedaan dan memandangnya sebagai suatu kekayaan bangsa. Menyikapi hal tersebut, Azyumardi Azra (Budimansyah dan Suryadi, 2008: 31) memandang bahwa pembentukan masyarakat multikultural Indonesia yang sehat tidak bisa secara taken for granted atau trial and error. Harus diupayakan secara sistematis, programatis, integrated dan berkesinambungan. Salah satu strategi penting itu adalah pendidikan multikultural yang dapat berlangsung dalam setting pendidikan formal atau informal, langsung atau tidak langsung.Sebagaimana dikemukakan oleh Richard Falk (Kymlicka, 2004:183) yang memandang bahwa "Keragaman masyarakat meningkatkan mutu hidup, dengan memperkaya pengalaman kita, memperluas sumber daya budaya”. Selain itu prinsip saling membutuhkan tanpa melihat latar belakang budaya, menjadi acuan terjadinya hubungan mutualis yang melahirkan integrasi antaretnik di tengah keragaman yang ada (Ramdhani, S, 2018). 


\section{KESIMPULAN}

Kesadaran akan adanyakeberagamanharus disadari dan disikapi dengan baik agar menjauhkan dari munculnya benih-benih perselisihan yang dapat memudarkan persatuan dan kesatuan bangsa Indonesia. Keragaman yang merupakan pemberian dari Tuhan ini dapat bermakna apabila setiap diri manusia menghargainya dengan penuh kesadaran.Semboyan Bhinneka Tunggal Ika yang bermakna persatuan ini harus dapat dipahami oleh masyarakat Indonesia. Hal tersebut dapat disosialisasikan melalui lembaga-lembaga tidak hanya lembaga pendidikan, tetapi juga di setiap lembaga pemerintah, swasta, lembaga masyarakat, lembaga keagamaan agar terwujudnya kehidupan masyarakat yang penuh dengan toleransi, saling menghargai, menghormati dan kehidupan yang selaras sesuai dengan nilai-nilai Pancasila.

\section{REFERENSI}

Bahar, Saafroedin. (1997). Elit dan Etnik serta Negara Nasional. Jurnal Prisma, (4) Tahun XXVI, April-Mei 1997.

Budimansyah, Dasim. (2016). Teori Sosial dan Kewarganegaraan. Bandung: Widya Aksara Press.

Budimansyah Dasim dan Suryadi Karim. (2008). PKn dan Masyarakat Multikultural. Bandung: Program Studi Pendidikan Kewarganegaraan

Faisal, Sanafiah. (1992). Format-format Penelitian Sosial. Jakarta: Rajawali Press.

Geertz, Hildred. (1967). Indonesian Culture and Communities, dalam Ruth T. McVey, ed. Indonesia, Southeast Asia Studies. New Haven: Yale University, by arrangement with HRAF Press.

Hanifi, Muhammad Luthfan. (2016). Ritual Perang dalam Kebudayaan Suku Dayak. Jurnal Sabda, 11(2), Desember 2016, hlm. 83-87.

Koentjaraningrat. (1970). Manusia dan kebudayaan di Indonesia. Anem Kosong Anem: Dambatan.

Kymlica (2004). Kewargaan Multikultural. Jakarta:LP3ES.

Latif, Yudi. (2011). Negara Paripurna: Historisitas, Rasionalitas, dan Aktualitas Pancasila. Jakarta: PT Gramedia Pustaka Utama.

Ramdhani, S. (2018). Konstruksi Nilai Multikulturalisme pada Masyarakat Haurgeulis Kabupaten Indramayu. Patanjala, 10(1), 1-16.

Risladiba, R., \& Sundawa, D. (2018, November). Implementation of Pancasila 
Values in Dayak Hindu-Budha Bumi Segandu Community to Make Good and Smart Citizens. In Annual Civic Education Conference (ACEC 2018) (pp. 402405). Atlantis Press.

Soedarso. (2006). Pengembangan Sistem Filsafat Pancasila. Jurnal Filsafat,39(1), April 2006, hlm. 42-56.

Suseno, Franz Magnis. (2005). Berebut Jiwa Bangsa-Dialog Persaudaraan dan Perdamaian. Jakarta: Kompas.

Widjaja. (2000). Penerapan Nilai-nilai Pancasila dan HAM di Indonesia. Jakarta: PT. Rineka Cipta. 